\title{
Uroperitônio secundário à ruptura focal da bexiga urinária durante parto eutócico em uma vaca Gir
}

Douglas Rodrigues do Nascimento Gonzaga;, Sara Engel, Michelle Endrey Godoy, Rodrigo Melo Meneses, Fabricio Gomes Melo, Layanne Duarte Ferreira, Elias Jorge Facury Filho, Antônio Último de Carvalho, Valentim Arabicano Gheller

Departamento de Clínica e Cirurgia Veterinárias, Escola de Veterinária, Universidade Federal de Minas Gerais (UFMG), Belo Horizonte, MG, Brasil

*Autor correspondente

e-mail: douglasgonzaga2009@hotmail.com

\section{Resumo}

O uroperitônio é caracterizado pelo acúmulo de urina na cavidade peritoneal, podendo ser oriundo da bexiga, rins, uretra e ureteres, e provoca uma resposta inflamatória irritativa do peritônio (peritonite química). A ruptura da bexiga é a principal causa de uroperitônio nos ruminantes, provocando uremia, caracterizada pelo aumento dos valores de ureia e creatinina séricas, associada à síndrome tóxica sistêmica. 0 presente trabalho relata um quadro de uroperitônio em uma fêmea bovina, da raça Gir Leiteiro, de 3 anos de idade, com oito dias pós-parto, atendida no Hospital Veterinário da UFMG em outubro de 2015. A queixa do proprietário era que o animal, desde o terceiro dia pós-parto, apresentava distensão abdominal bilateral progressiva, apatia e redução do consumo de alimento. Ao exame físico, observou-se depressão, taquipneia, taquicardia, vasos episclerais ingurgitados, desidratação intensa (10\%), anorexia, atonia rumenal, grande quantidade de líquido livre no abdômen, polaciúria, oligúria e disúria. O líquido peritoneal apresentou-se de aspecto límpido e incolor, com densidade específica 1,015, proteína total 0,6 g/dL, predomínio de neutrófilos (95\%), discreta concentração de bactérias e valores de ureia e creatinina de $231,7 \mathrm{mg} / \mathrm{dL}$ e $32 \mathrm{mg} / \mathrm{dL}$, respectivamente. Na bioquímica sérica, verificou-se valores de ureia de 101,9 mg/dL e creatinina de $6 \mathrm{mg} / \mathrm{dL}$. O hemograma demonstrou leucocitose $\left(28.000 / \mathrm{mm}^{3}\right)$ por neutrofilia $\left(17.080 / \mathrm{mm}^{3}\right)$, linfocitose $\left(8.680 / \mathrm{mm}^{3}\right)$ e monocitose $\left(2.240 / \mathrm{mm}^{3}\right)$. Havia, ainda, moderada hematúria e discreta glicosúria e proteinúria. Diante do quadro clínico compatível com uroperitônio, recomendou-se a laparotomia exploratória. Durante a cirurgia, $80 \mathrm{~L}$ de um líquido translúcido com odor de urina foram drenados da cavidade peritoneal, sendo encontrado um ponto de ruptura com 1,5 cm de diâmetro na inserção do úraco patente. Após a exploração da cavidade abdominal e retirada do líquido, foi realizada a cistorrafia e exérese do úraco. Durante o procedimento cirúrgico, devido à hipotensão gerada pela retirada do fluído peritoneal, foi necessária a administração 
intravenosa de solução salina hipertônica 7,5\% (4 mL/kg), seguida por infusão de $10 \mathrm{~L}$ de solução Ringer Lactato, IV. Durante o pós-operatório foi administrado $3 \mathrm{mg} / \mathrm{kg}$ de Ceftiofur, IM, SID, durante 10 dias; $2 \mathrm{mg} / \mathrm{kg}$ de Flunixin Meglumine, IV, SID, durante três dias; 30 L de solução Ringer Lactato, IV, nas primeiras 24 horas; 10 L de fluído ruminal, duas horas após a laparotomia; e 15 L de solução hidroeletrolítica, VO, BID, durante três dias. A alta médica ocorreu dez dias após a internação, quando o animal apresentou exame clínico sem alterações, leucograma normal (6.180 leucócitos $\left./ \mathrm{mm}^{3}\right)$, restabelecimento da ingestão de alimentos e comportamento ativo. A tensão sobre o úraco patente durante o parto possivelmente provocou a ruptura focal da bexiga. A correção cirúrgica e o pós-operatório foram eficientes na resolução do quadro e recuperação da paciente. 